\title{
Major Trends in the Historiography of European Ashkenazic Jews from the 1970s to the Present
}

\author{
KLAUS HÖDL \\ Center for Jewish Studies, University of Graz, Graz, Austria \\ E-mail:klaus.hoedl@uni-graz.at
}

Accepted: 9 February 2021 / Published online: 23 August 2021

\begin{abstract}
This article focuses on shifts in Jewish historiography of Ashkenazic Jews in Europe of the pre-modern period. It describes the denouement of traditional historiographywhich generally assumes that more often than not Jews and non-Jews lived separate from one another-and compares it to two trends that I denominate exchange and interaction historiography that have gained momentum from the last third of the twentieth century. In contrast to scholars working in the traditional vein, exchange and interaction historians view Jews and non-Jews as interconnected and entangled. Exchange historians deal primarily with Jewish and non-Jewish cultural interrelatedness, whereas interaction historians overwhelmingly focus on interpersonal contacts. I use the terms exchange and interaction historiography because they comprehensibly flag as well as qualify distinctions in post-traditional historiography's conception of Jewish and non-Jewish relations. Methodologically, however, there is considerable overlap between these three historiographical approaches insofar as they all employ the concept of difference as a central analytical tool. The notion of difference prompts scholars to focus first and foremost on what distinguished Jews and non-Jews instead of what they shared, and consequently to depict their relations as dichotomous. In this article, I argue that the insistence on the Jewish/non-Jewish binary forestalls possible innovations that exchange and interaction historians might otherwise pioneer in their approaches. The proposed remedy for this predicament is to replace difference with similarity as an analytical instrument and to focus on intercultural commonalities rather than distinctions. Various scholars have already made efforts to transcend the Jewish/non-Jewish binary but have fallen short of achieving their goal by failing to base their work on a sufficiently rigorous conceptual framework, such as similarity.
\end{abstract}

Keywords Historiography $\cdot$ Ashkenazim $\cdot$ Microhistory $\cdot$ Jewish and non-Jewish encounters $\cdot$ Entanglement

How we view the history of Jews has drastically changed in the recent past. ${ }^{1}$ Various scholars posit that, apart from a few exceptions, before the last third of the twentieth century historians described traditional Jews-particularly the greater part of Ashkenazic Jewry from the High Middle Ages until the onset of modernity—as living in cultural and largely social isolation from its

\footnotetext{
${ }_{1}^{1}$ Israel Bartal and Scott Ury, "Between Jews and their Neighbours: Isolation, Confrontation, and Influence in Eastern Europe," Polin 24 (2012): 3-30.
} 
non-Jewish environment, ${ }^{2}$ their interactions overwhelmingly restricted to the economic realm. ${ }^{3}$ These historians, ${ }^{4}$ whom I designate traditional historians, considered the relations between Jews and non-Jews ${ }^{5}$ as restrained at best; more often, they were marked by hostility. ${ }^{6}$

This article examines historiographical trends relating to Ashkenazic Jews in Europe, published mostly in English in roughly the last forty years. In the early 1980s a new generation of historians, whom I wish to classify as either exchange or interaction historians, began to offer narratives of the Jewish past markedly different from the portrayal in traditional historiography. ${ }^{7}$ So-

\footnotetext{
${ }^{2}$ Moshe Rosman, "A Jewish Guide to Medieval Domestic Europe," review of Mothers and Children: Jewish Family Life in Medieval Europe, by Elisheva Baumgarten, Jewish Quarterly Review 98 (2008): 419; Francesca Bregoli, "Introduction," in Connecting Histories: Jews and Their Others in Early Modern Europe, ed. Francesca Bregoli and David B. Ruderman (Philadelphia, 2019), 10. Concerning the exceptions, see David Berger, "A Generation of Scholarship on Jewish-Christian Interaction in the Medieval World," Tradition 38, no. 2 (2004): 5. One of the most important scholars of the history of Jews was Salo W. Baron (1895-1989), who dealt early on in his career with "elements and areas of cross-fertilization between Jews and their environment." See Arthur Hertzberg, "Baron, Salo (Shalom) Wittmayer," in Encyclopaedia Judaica 4:254. Other early scholars who should be ranked as exceptions were Israel Abrahams, Jewish Life in the Middle Ages (London, 1896; repr., New York, 1969); Moritz Güdemann, Geschichte des Erziehungswesens und der Kultur der abendländischen Juden, 3 vols. (Vienna, 1880-1888); and Cecil Roth, The Jews in the Renaissance (New York, 1959). On how historians of the Jewish past approach Jewish and non-Jewish relations, see also Adam Teller and Magda Teter, "Introduction: Borders and Boundaries in the Historiography of the Jews in the Polish-Lithuanian Commonwealth," Polin 22 (2010): 3-46.

${ }^{3}$ Jacob Katz, Tradition and Crisis: Jewish Society at the End of the Middle Ages, trans. Bernard Dov Cooperman (New York, 1993), 22.

${ }^{4}$ Prominent representatives of this "historiographical camp" include early Israeli medieval historians, such as Yitzhak Baer, Haim Hillel Ben-Sasson, and Ben-Zion Dinur. Although they recognized some non-Jewish influences on Jews, they rejected the idea that these influences had an essential impact on their history. Instead, they saw it driven by particular inner-Jewish forces. See Ivan G. Marcus, "Israeli Medieval Jewish Historiography: From Nationalist Positivism to New Cultural and Social Histories," Jewish Studies Quarterly 17 (2010): 244-85. Some historians still write in the vein of traditional historiography. See, for example, Robert Blobaum, ed., Antisemitism and Its Opponents in Modern Poland (Ithaca, NY, 2005), 2.

5 "Non-Jews" refers primarily to Christians, rather than to Muslims or any other religious or ethnic group.

${ }^{6}$ On the idea of continuous Jewish suffering in the diaspora, see Robert Chazan, Refugees or Migrants: Pre-Modern Jewish Population Movement (New Haven, CT, 2018).

${ }^{7}$ Among the most outstanding innovative scholars were Ivan G. Marcus, Piety and Society: The Jewish Pietists of Medieval Germany (Leiden, 1981); Kenneth Stow, Alienated Minority: The Jews of Medieval Latin Europe (Cambridge, MA, 1992); and Mark R. Cohen, Under Crescent and Cross: The Jews in the Middle Ages (Princeton, 1996). Regarding the new historiographical trends, see also William Chester Jordan, "Jewish Studies and the Medieval Historian," Exemplaria 12 (2000): 7-20. The reasons for the shift in perspective are varied and may
} 
called exchange historians primarily investigate processes of cultural transfer between Jewish and non-Jewish communities. ${ }^{8}$ Interaction historians concentrate on the history of interpersonal encounters and relationships. ${ }^{9}$ Both these types have reassessed the Jewish past, revised historical narratives, and formulated new research questions, thereby enlarging our scope of knowledge of Jewish history. Yet, in their common use of difference as a central analytical tool, and their continued description of Jewish/non-Jewish relations as dichotomous, exchange and interaction historians have perpetuated an aspect of traditional historiography's perspective that clearly limits their potentially innovative and promising approaches. I argue that scholars may overcome the deadlock by substituting similarity in place of difference as an analytical instrument and focusing on intercultural commonalities rather than distinctions.

be linked to the emergence of social history and microhistory (see below), to the epistemic effects of postcolonialism and its study of cultural interaction, and to the demise of a Jewish historiography that focused on inner-Jewish dynamics. Also important in this regard is Gerson D. Cohen's reconceptualization of the term assimilation in his 1966 essay; see his "The Blessing of Assimilation in Jewish History," in idem, Jewish History and Jewish Destiny (New York, 1997), 45-56. On its impact on students of Jewish history, see David B. Ruderman, "The Blessing of Gerson D. Cohen," Jewish Quarterly Review 106 (2016): 459-64. Many of them no longer considered the adoption of culture from the non-Jewish cultural sphere a threat to Judaism, and consequently rendered mutual Jewish and non-Jewish cultural borrowing and adaptation a legitimate subject of research.

${ }^{8}$ In using a broad notion of culture, cross-cultural contacts include all forms of cultural articulation, including texts, practices, and beliefs, among others. An illustrative representative of an exchange historian is Elisheva Carlebach. She writes that Jews and Christians interpreted "historical and natural events in light of their respective theological traditions," yet, she adds, "their religious imaginations collided, converged, and reverberated in an endless cycle which continually reworked mutual perceptions and definitions." See Elisheva Carlebach, "Jews, Christians, and the Endtime in Early Modern Germany," Jewish History 14 (2000): 331.

${ }^{9}$ My division of Jewish historiography into exchange and interaction historiography is based on two considerations. First, it reflects major trends regarding how historians have approached the Jewish past in the last few decades. Secondly, it opens up a path to problematize the usage of difference as an analytical tool in Jewish studies. As may be expected, some historical accounts cannot be assigned to only one of my proposed categories, but straddle both of them. See, for example, Debra Kaplan, "'Because Our Wives Trade and Do Business with Our Goods': Gender, Work, and Jewish-Christian Relations," in New Perspectives on JewishChristian Relations, ed. Elisheva Carlebach and Jacob J. Schacter (Leiden, 2011), 241-61. In sum, however, these examples do not invalidate my overall classification. 


\section{Characteristics of Exchange and Interaction Historiography}

A core tenet of the exchange narrative is the assertion that the Jewish cultural and religious spheres were multifariously related to non-Jewish domains and that the mutual exchanges affected both sides. ${ }^{10}$ According to this notion of Jewish and non-Jewish interdependence, various facets of Judaism and Christianity were shaped reciprocally, which extended to the cultural selfunderstanding of both Jews and non-Jews and to multiple aspects of their daily lives. ${ }^{11}$ Most historians no longer view Jews as having eked out an existence solely as a persecuted minority that lacked agency in an inimical non-Jewish environment. ${ }^{12}$ Despite frequently pervasive Judeophobia, Jews participated in the society in which they lived. ${ }^{13}$

In addition to a revised understanding of the role of Jews in the shaping of the cultures of their societies, the new conception of relations between Jews and non-Jews introduced an entire range of previously neglected research topics. For example, in deviating from the binary of non-Jewish perpetration and Jewish victimhood, scholars displayed greater willingness to explore the role of Jewish aggressors ${ }^{14}$ and the issue of Jewish intracommunal violence. ${ }^{15}$

\footnotetext{
${ }^{10}$ Elisheva Carlebach and Jacob J. Schacter, "Introduction," in idem, New Perspectives on Jewish-Christian Relations, 1.

${ }^{11}$ Debra Kaplan and Magda Teter, "Out of the (Historiographic) Ghetto: European Jews and Reformation Narratives," Sixteenth Century Journal 40 (2009): 365-94. Ground-breaking publications to be mentioned in this context are Israel J. Yuval, Two Nations in Your Womb: Perceptions of Jews and Christians (Berkeley, 2006) as well as Elisheva Carlebach, Palaces of Time: Jewish Calendar and Culture in Early Modern Europe (Cambridge, MA, 2011). In addition, see David B. Ruderman, ed., Essential Papers on Jewish Culture in Renaissance and Baroque Italy (New York, 1992), and Jeremy Cohen, Sanctifying the Name of God: Jewish Martyrs and Jewish Memories of the First Crusade (Philadelphia, 2004). See also Jay R. Berkovitz, Law's Dominion. Jewish Community, Religion, and Family in Early Modern Metz (Leiden, 2020).

${ }^{12}$ Criticism of the perspective of the Jewish diaspora as a period of ongoing tribulations and hostility perpetrated by non-Jews was voiced long before the late twentieth century. Salo Baron, already in the late 1920s, called for discarding the "lachrymose conception of Jewish history." See Salo Baron, "Ghetto and Emancipation: Shall We Revise the Traditional View?" Menorah Journal 14 (1928): 515-26. Concerning Salo Baron as a historian, see Robert Chazan, "A New Vision of Jewish History: The Early Historical Writings of Salo Baron," AJS Review 39 (2015): 27-47.

${ }^{13}$ See Ivan G. Marcus, "Israeli Medieval Jewish Historiography: From Nationalist Positivism to New Cultural and Social Histories," Jewish Studies Quarterly 17 (2010): 281.

${ }^{14}$ Elliott Horowitz, Reckless Rites: Purim and the Legacy of Jewish Violence (Princeton, 2006).

${ }^{15}$ See Gershon David Hundert, "Leibush the Lawless and His Border Tavern," in Bregoli and Ruderman, Connecting Histories, 183. Edward Fram, Ideals Face Reality: Jewish Law and
} 
Another characteristic indicative of scholars concerned with cultural exchange is their focus on collectives rather than individuals as agents of cultural borrowing. ${ }^{16}$ These scholars seem to be more interested in exploring whether Jews adopted cultural norms from the non-Jewish sphere (or vice versa) and adapted them to their own cultural context, rather than investigating whether, how, and to what extent individuals contributed to these processes. After all, the role that individual Jews have played in cultural transfer often appears extraneous or untraceable. ${ }^{17}$

In contrast to the exploration that their peers undertake regarding cultural interdependency, interaction historians primarily investigate Jewish and nonJewish contacts at an individual level. One of the cardinal questions these scholars often struggle to answer is whether or how interethnic contacts affected Jewish and non-Jewish relations and coexistence. ${ }^{18} \mathrm{~A}$ further distinction between interaction historians and exchange historians lies in their respective understanding of boundaries. Whereas the latter tend to emphasize the existence of clear, albeit at times decidedly porous, demarcations between

Life in Poland, 1550-1655 (Cincinnati, 1997), 60. Ilan Greilsammer, La nouvelle histoire d'Israël: Essai sur une identité nationale (Paris, 1998), 80-81. In this context, I must mention that various historians' endeavors to compose historical accounts without the notion of Jews as partial victims resulted in highly controversial publications, such as Israel J. Yuval's "Vengeance and Damnation, Blood and Defamation: From Jewish Martyrdom to Blood Libel Accusations" [in Hebrew], Zion 58 (1993): 33-90. On Yuval's essay, see also Hannah R. Johnson, Blood Libel: The Ritual Murder Accusation at the Limit of Jewish History (Ann Arbor, 2012), 92-123. A particularly divisive book is Ariel Toaff's Pasque di sangue: Ebrei d'Europa e omicidi rituali (Bologna, 2007). He claims that some Ashkenazic Jewish communities used blood of Christian children during Passover to prepare a specific version of matzot. Concerning the debate on Toaff's publication, see Sabina Loriga, "Une vieille affaire? Les 'Pâques de sang' d'Ariel Toaff," Annales 63 (2008): 143-72.

${ }^{16}$ Jonathan Ray, "Beyond Tolerance and Persecution: Reassessing Our Approach to Medieval 'Convivencia'," Jewish Social Studies 11, no. 2 (2005): 9.

${ }^{17}$ Jewish and Christian marriage rituals in the medieval period may serve as an illustrative example. Over time, they underwent a mutual adaptation caused by Jews' observation of Christian performances and vice versa, rather than by personal contact. See Esther Cohen and Elliott Horowitz, "In Search of the Sacred: Jews, Christians, and Rituals of Marriage in the Later Middle Ages," Journal of Medieval and Renaissance Studies 20 (1990): 225-49, and Debra Kaplan, "Rituals of Marriage and Communal Prestige: The Breileft in Medieval and Early Modern Germany," Jewish History 29 (2015): 273-300. Elisheva Baumgarten writes in this context: "Even if one could argue based on historical evidence, that there was little or no direct contact between the different religious groups, ... sources from medieval England, France, Germany, Italy and Spain, as well as north African sources demonstrate an awareness of the practices of majority and minority religions." See Elisheva Baumgarten, “'A Separate People'? Some Directions for Comparative Research on Medieval Women," Journal of Medieval History 34 (2008): 214.

${ }^{18}$ Eugene M. Avrutin, "Jewish Neighbourly Relations and Imperial Russian Legal Culture," Journal of Modern Jewish Studies 9 (2010): 2. 
Jews and non-Jews and argue that cooperation between them represents only one side of complex, frequently also hostile, relations, ${ }^{19}$ interaction historians seem eager to question the function of borders as dividing lines. ${ }^{20}$ They see these ostensible dividing lines instead as areas of contact where social interaction unfolds ${ }^{21}$ and common ground between Jews and non-Jews develops. $^{22}$

Consistent with this conception of boundaries are some interaction historians' efforts to reinterpret various Jewish/non-Jewish conflicts by questioning their anti-Jewish motives. Eugene M. Avrutin, for example, researched everyday relations between Jews and non-Jews in imperial Russia. He convincingly demonstrates that an investigation of their everyday lives undermines conventional interpretations of clashes between Jews and non-Jews. Rather than being classified as interethnic violence, most of these clashes represent

\footnotetext{
${ }^{19}$ Robert Bonfil has described such a constellation in reference to Jews in Italy in the sixteenth century. He has argued that Jews and non-Jews experienced increased segregation from and reduced contacts between each other. At the same time, the knowledge of Hebrew among Jews deteriorated, while their Italian language skills improved. That is to say, cultural exchange between Jews and non-Jews increased at a time when interethnic and interreligious boundaries strengthened and ghettos were established. See Robert Bonfil, "Change in the Cultural Patterns of a Jewish Society in Crisis: Italian Jewry at the Close of the Sixteenth Century," Jewish History 3, no. 2 (1988): 11-30.

${ }^{20}$ The different perspectives manifest themselves in a controversy among historians who focus on Italian Jews. While Robert Bonfil, whom I consider an exchange historian, argues that sexual contacts between Jews and gentiles were rare and taboo, and thereby refrains from questioning clear Jewish and non-Jewish boundaries, other historians, such as Thomas Cohen and Ariel Toaff, maintain that an attitude of indifference towards sexual contacts prevailed and that they were a fairly frequent occurrence. See Robert Bonfil, "Jews, Christians, and Sex in Renaissance Italy: A Historiographical Problem," Jewish History 26 (2012): 101-11; Thomas Cohen, "The Death of Abramo of Montecosaro," Jewish History 19 (2005): 278-79; Ariel Toaff, Love, Work, and Death: Jewish Life in Medieval Umbria, trans. Judith Landry (London, 1996).

${ }^{21}$ Teller and Teter, "Introduction: Borders and Boundaries." In this context, the role of apostates may serve as an example that confirms this assertion. These apostates, especially serial apostates who converted back and forth, continuously crossed interreligious demarcations or lived in the realm of these boundaries. See David Joshua Malkiel, "Jews and Apostates in Medieval Europe - Boundaries Real and Imagined," Past \& Present 194 (February 2007): 3-34. On the notion of contact zone, see Mary Louise Pratt, Introduction: Criticism in the Contact Zone, in eadem, Imperial Eyes: Travel Writing and Transculturation (London, 1992), 1-11.

${ }^{22}$ Victoria Hoyle, "The Bonds that Bind: Moneylending between Anglo-Jewish and Christian Women in the Plea Rolls of the Exchequer of the Jews, 1218-1280," Journal of Medieval History 34 (2008): 119-29; Monica H. Green, "Conversing with the Minority: Relations among Christian, Jewish, and Muslim Women in the High Middle Ages," Journal of Medieval History 34 (2008): 105-18.
} 
commonplace tensions - an outgrowth of neighborly relations, lacking a specific anti-Jewish animus. ${ }^{23}$

My division of Jewish historiography into three different approaches is primarily based on differing views of Jewish and non-Jewish relations. In some respects, these approaches also show partial congruence, indicating that they represent trends rather than clear-cut categorizations. Such an overlap comes paradigmatically to the fore with regard to the analytical methods that exchange and traditional historians apply. Both groups tend to focus on the Jewish elite rather than ordinary Jews. Among exchange historians, this approach is often the direct result of the specific topics they explore. For instance, issues concerning the mutual influence of Jews and non-Jews in the fields of biblical exegesis and religious rituals and writings overwhelmingly deal with intellectual history.

As the example of Christian Hebraism vividly illustrates, a partial overlap proves true for the classification in exchange and interaction historiography as well. Christian Hebraists doggedly strove to read Jewish religious texts in the original language, and to acquire or improve the necessary language skills they took Hebrew lessons with Jews. Hebraists also employed Jews as proofreaders of their translations into German, borrowed books from Jews, and sought personal contacts with them for various other purposes. ${ }^{24}$ The entire phenomenon of Christian Hebraism, an illustrative instance of cultural exchange, was thus strongly fostered by personal encounters, and exchange historians researched them accordingly.

A further reason for the growing relevance of face-to-face contacts in exchange historians' research is related to their insight that Jews and non-Jews of a given region often not only faced the same challenges ${ }^{25}$ but also interpreted these challenges and attempted to meet them in a remarkably similar manner. This correlation strongly suggests that Jews and non-Jews possessed at least in part a common mindset resulting from regular interactions. ${ }^{26}$

\footnotetext{
${ }^{23}$ Avrutin, "Jewish Neighbourly Relations," 1-16.

${ }^{24}$ Debra Kaplan, Beyond Expulsion: Jews, Christians, and Reformation Strasbourg (Stanford, 2011), 119-43. See also Allison P. Coudert and Jeffrey S. Shoulson, eds., Hebraica Veritas? Christian Hebraists and the Study of Judaism in Early Modern Europe (Philadelphia, 2004). Also see Anthony Grafton and Joanna Weinberg, 'I Have Always Loved the Holy Tongue': Isaac Casaubon, the Jews, and a Forgotten Chapter in Renaissance Scholarship (Cambridge, MA, 2011).

${ }^{25}$ Debra Kaplan, "The Self in Social Context: Asher ha-Levi of Reichshofen's Sefer Zikhronot," Jewish Quarterly Review 97 (2007): 228.

${ }^{26}$ Elisheva Baumgarten, Mothers and Children: Jewish Family Life in Medieval Europe (Princeton, NJ, 2004), 8. See in this context also Robert Liberles, Jews Welcome Coffee: Tradition and Innovation in Early Modern Germany (Waltham, MA, 2012).
} 


\section{The Growing Importance of Interaction Historians}

Interaction historiography gained momentum in the 1990s. In general, interaction historiography refutes more thoroughly than exchange historiography the central propositions of traditional historians who aver that Jews lacked agency and largely lived apart from non-Jews. This is due in part to the analytical approach of interaction historians, which frequently focuses on everyday life. ${ }^{27}$ Microhistory's main research subjects ${ }^{28}$ - the mundane practices of ordinary people rather than the achievements of a small elite-as well as widening the scope of agency to include all people, contradict the image of Jews that traditional historiography presents. ${ }^{29}$ This contrast is further corroborated by microhistory's aim to trace the complex network "of familial and extrafamilial social relations in a small community" 30 as constituted by daily activities. ${ }^{31}$ In the face of steadily growing historical evidence that Jews lived in close proximity to non-Jews and interacted on a daily basis with their neighbors, ${ }^{32}$ interaction historians' study of the everyday focuses on reconstructing encounters of Jews with non-Jews, irrespective of whether they were hostile or peaceful. ${ }^{33}$ Taking into consideration Lara Putnam's assertion

\footnotetext{
${ }^{27}$ At this point, I wish to emphasize that interaction historiography is not congruent with microhistory. Although interaction historiography heavily draws on microhistorical analytical approaches, it usually endeavors to answer large-scale research questions.

${ }^{28}$ There are differences as well as similarities between everyday history and microhistory. On differences between the two concepts, see Brad S. Gregory, "Is Small Beautiful? Microhistory and the History of Everyday Life," History and Theory 38 (1999): 103-04. In this article, differences between them are not significant, and the two terms therefore are used as widely interchangeable.

${ }^{29}$ This is the case, for example, when research findings propose that Jews did not lack agency and were not only victims of discrimination and persecution, but also figured as aggressors. See Adam Teller, "The Shtetl as an Arena for Polish-Jewish Integration in the Eighteenth Century," Polin 17 (2004): 38.

${ }^{30}$ Andrew I. Port, "History from Below, the History of Everyday Life, and Microhistory," International Encyclopedia of the Social \& Behavioral Sciences, ed. James D. Wright, 2nd ed. (Amsterdam, 2015), 11:108-13.

${ }^{31}$ Francesca Trivellato, "Microhistoria/Microhistoire/Microhistory," French Politics, Culture \& Society 33, no. 1 (2015): 123.

${ }^{32}$ This has been the case in different geographical areas and during various periods. See, for example, Jeffrey Gorsky, Exiles in Sepharad: The Jewish Millennium in Spain (Lincoln, NE, 2015), 26; Heather J. Sharkey, A History of Muslims, Christians, and Jews in the Middle East (Cambridge, UK, 2017); Leonard Victor Rutgers, "Archaeological Evidence for the Interaction of Jews and Non-Jews in Late Antiquity," American Journal of Archaeology 96 (1992): 101-18.

${ }^{33}$ Even Jews who lived inside the ghetto walls interacted with non-Jews outside the ghetto, as research has convincingly demonstrated. See, for example, Robert C. Davis and Benjamin Ravid, eds., The Jews of Early Venice (Baltimore, 2001).
} 
that "microhistory has the most impact in cases in which prior assumptions of separation were so strong and so fundamental that the mere demonstration of such connections forces readers to reconsider basic claims about the societies within which the connections were found," 34 it is even safe to say that an exploration of the Jewish quotidian practices profoundly disproves traditional historiography's assumption of a Jewish/non-Jewish divide.

Traditional historians often overlooked or dismissed Jewish and nonJewish entanglement. Among the reasons was their tendency to interpret regulations proscribing Jewish and non-Jewish socializing as indicative of their societal and cultural divide. ${ }^{35}$ This conclusion is fallacious on at least three grounds. First, pertinent laws, decrees, and ordinances issued by both Jewish and non-Jewish authorities were frequently in response to the intermingling of Jews and non-Jews and bespeak their togetherness rather than their alienation from each other. ${ }^{36}$ Second, depending on the societal context, these regulations sometimes remained dead letters, hardly enforced and therefore without much impact on daily practice. ${ }^{37}$ And third, legal norms do not determine people's behavior. To an extent, people are able to decide themselves whether to comply with or defy regulations. As the recently deceased German historian of the everyday Alf Lüdtke claimed, individuals possess a characteristic that he called Eigen-Sinn, ${ }^{38}$ a "sliver of autonomy ... that allow[ed them] ... to navigate below the structures that older social history

\footnotetext{
${ }^{34}$ Lara Putnam, "To Study the Fragments/Whole: Microhistory and the Atlantic World," Journal of Social History 39 (2006): 616.

${ }^{35}$ Hundert, "Leibush the Lawless and His Border Tavern," 180.

${ }^{36}$ Magda Teter, “'There Should be No Love Between Us and Them': Social Life and the Bounds of Jewish and Canon Law in Early Modern Poland," Polin 22 (2010): 249-70.

${ }^{37}$ There are myriad examples of Jews as well as non-Jews defying rules, commandments, and laws. In antiquity, for instance, interconfessional marriages and conversions without a rabbi steadily undermined the rabbinical definition of Jewishness based on descent from a Jewish mother or rigid conversion rituals. See Jeffrey M. Perl, Natalie Zemon Davis, and Barry Allen, "Fuzzy Studies: A Symposium on the Consequence of Blur, Part I," Common Knowlege 17 (2011): 447. The ordinances of the IV Lateran Council regarding the identification of Jews were also frequently disregarded. See Léon Poliakov, Geschichte des Antisemitismus, vol. 1, Von der Antike bis zu den Kreuzzügen (Worms, 1979), 56-58. See also Jonathan Ray, "Beyond Tolerance and Persecution: Reassessing Our Approach to Medieval "Convivencia'," Jewish Social Studies 11, no. 2 (2005): 5; Larry J. Simon, "Jews, Visigoths, and the Muslim Conquest of Spain,” UCLA Historical Journal 4 (1983): 5-33.

${ }^{38}$ Alf Lüdtke, Eigen-Sinn: Fabrikalltag, Arbeitererfahrungen und Politik vom Kaiserreich bis in den Faschismus (Hamburg, 1993). For other scholars who also draw attention to this aspect, see Michel de Certeau, The Practice of Everyday Life, trans. Steven Rendall (Berkeley, 1988); Rita Felski, "Introduction: Everyday Life," New Literary History 33 (2002): 611-12; and Filippo de Vivo, "Prospect or Refuge? Microhistory, History on the Large Scale: A Response," Cultural and Social History 7 (2010): 388.
} 
relied on." ${ }^{39}$ One may assume that both ordinary Jews and non-Jews did not always abide by regulations meant to sever the ties between them. ${ }^{40}$ If we apply the notion of Eigen-Sinn, microhistory provides a possible answer to the question of what accounted for Jewish/non-Jewish contacts despite efforts by religious and secular authorities to thwart them.

\section{The Turn to the Everyday and its Effects in Jewish Studies}

Various factors propelled scholars of Jewish Studies to turn to the history of the everyday. Two seem to have been of particular importance. The first is rooted in the growing prominence of a social history approach among historians of the Jewish past. Since, as Todd M. Endelman argues, social history is a "history from the bottom up, history that made room for persons who were neither distinguished nor wealthy," 41 these historians either included underprivileged and marginal people in their broader work or investigated them as primary subjects. ${ }^{42}$ The turn to social history opened up new fields of research that traditional historians had largely disregarded, such as the seemingly banal experiences of common people, their lifeways, and quotid-

\footnotetext{
${ }^{39}$ Maria Bucur, Rayna Gavrilova, Wendy Goldman, Maureen Healey, Kate Lebow, and Mark Pittaway, "Six Historians in Search of Alltagsgeschichte," Aspasia 3 (2009): 189-212.

${ }^{40}$ See Ulrich Baumann, “'Gell, Raphael, wir gehen heim, mir wö’n heim': Heimaten, Heimat, Idylle, Gewalt; Ein Rückblick auf die Beziehungen von Christen und Juden in Südbadischen Landgemeinden," Allmende 17, no. 54-55 (1997): 208. In southern Germany, for example, National Socialists complained of peasants who defied their regulations demanding that nonJewish Germans boycott Jews and sever all commercial ties with them.

${ }^{41}$ Todd M. Endelman, "In Defense of Jewish Social History," Jewish Social Studies 7, no. 3 (2001): 55 .

${ }^{42}$ With its pronounced cultural bias, this understanding of social history was largely limited to Anglo-Saxon historiography. See Todd M. Endelman, Broadening Jewish History: Towards a Social History of Ordinary Jews (London, 2014), 12. It must not be confounded with the German Sozialgeschichte that was more of a social science history that focused on supraindividual structures and diminished the individual to insignificance. To a certain extent, German Alltagsgeschichte may be understood as the German version of social history. See Geoff Eley, "Labor History, Social History, Alltagsgeschichte: Experience, Culture, and the Politics of the Everyday - A New Direction for German Social History?" Journal of Modern History 61 (1989): 315. The emergence of the history of the everyday was not only related to a shift of focus to new realms of research and to a rejection of the quantification methodology. It also was connected with a renaissance of the narrative and with placing the individual as an agent, rather than circumstances, in the center of historical investigation. See Lawrence Stone, "The Revival of Narrative: Reflections on a New Old History," Past \& Present 85 (1979): 3-24; Lynn Hunt, "Introduction: History, Culture, and Text," in The New Cultural History, ed. Lynn Hunt (Berkeley, 1989), 1-22.
} 
ian practices. ${ }^{43}$ The second reason for Jewish Studies' engagement with the everyday is related to the demise of the Soviet Union and the access scholars gained to a wide range of previously unavailable archival material. ${ }^{44}$ The analysis of this material yielded many insights into the daily practices of Polish and Russian Jews,${ }^{45}$ imparting fresh energy to the study of the everyday.

During most of the late medieval period, Jews in Eastern Europe appeared to have had more opportunities to interact with their non-Jewish social environment than those in parts of central and Western Europe ${ }^{46}$ who suffered from anti-Jewish accusations (such as blood libel and desecration of the host) ${ }^{47}$ from the pressure to seclude themselves, ${ }^{48}$ and the consequences of expulsion orders. ${ }^{49}$ The turn to the everyday by historians of Eastern European Jews resulted in particularly rich accounts of Jewish/non-Jewish entanglement. Recent research led to the conclusion that many Jews and non-Jews encountered one another on a daily basis, maintained neighborly relations, visited each other, and were familiar with their respective private spheres. ${ }^{50}$

${ }^{43}$ As is evident from its title, Salo Baron's Social and Religious History was meant in part as social history. It is the subject of some debate, however, whether his work meets the criteria of social history. As Jacob Neusner states: "What we find is not social history at all, but mere collections of references to texts deemed relevant to the theme at hand." See Jacob Neusner, "When Intellectual Paradigms Shift: Does the End of the Old Mark the Beginning of the New?" History and Theory 27, no. 3 (1988): 258. Another remarkable book that contains a social history approach and was published before the last third of the twentieth century was Israel Abrahams's Jewish Life in the Middle Ages.

${ }^{44}$ Eric L. Goldstein, "Beyond the 'Shtetl': Small-Town Family Networks and the Social History of Lithuanian Jews," Jewish Social Studies 24, no. 1 (2018): 36.

${ }^{45}$ See for example Glenn Dynner, Yankel's Tavern: Jews, Liquor, \& Life in the Kingdom of Poland (Oxford, 2014); Yohanan Petrovsky-Shtern, The Golden Age Shtetl: A New History of Jewish Life in Eastern Europe (Princeton, NJ, 2014).

${ }^{46}$ It may be worth differentiating between rural Jews living in small villages (Landjuden) and those inhabiting towns and cities. The former, so it seems, socialized with non-Jews to a greater extent than those residing in urban locations. See Mark Häberlein and Michaela Schmölz-Häberlein, "Competition and Cooperation: The Ambivalent Relationship between Jews and Christians in Early Modern Germany and Pennsylvania," Pennsylvania Magazine of History and Biography 126 (2002): 409-36.

${ }^{47}$ In comparison to western and central Europe, these accusations emerged in Eastern Europe with a considerable time lag. The stereotype of ritual murder, for example, first emerged in England in mid-twelfth century. It was not before the early sixteenth century that this prejudice made a foray in Eastern Europe. See Robert Weinberg, "The Blood Libel in Eastern Europe," Jewish History 26 (2012): 278.

${ }^{48}$ Yosef Hayim Yerushalmi, "Medieval Jewry: From Within and From Without," in Aspects of Jewish Culture in the Middle Ages, ed. Paul E. Szarmach (Albany, 1979), 1-26.

${ }^{49}$ Jews were expelled from England in 1290, from France in 1309, from Germany in 1348, from Spain in 1492, from Portugal in 1497, and from numerous cities and smaller territories. ${ }^{50}$ Jacob Goldberg, "Poles and Jews in the 17th and 18th Centuries: Rejection and Acceptance," Jahrbücher für Geschichte Osteuropas 22 (1974): 259. We can observe this trend in research in 
Some Jews lived in non-Jewish households and vice versa, ${ }^{51}$ ate and drank with one another, ${ }^{52}$ participated in festivities and sang together, ${ }^{53}$ assisted each other in times of distress, ${ }^{54}$ and even maintained extramarital sexual relations. ${ }^{55}$

The preoccupation with ordinary Jews and their daily experiences had immediate repercussions on historians' conception of Jewishness, and consequently on Jewish historiography. In analyzing the embeddedness of Jews in local societal contexts, microhistory significantly contributed to a differentiation among Jews, and consequently to the notion of plural forms of Jewishness and manifold Jewish cultures shaped by their respective environments. ${ }^{56}$ The issue of Jewish modernization illustrates how an investigation of common people and their quotidian activities revises the notion of a unified Jewry. So long as historians focused primarily on the erudite Jewish elite and articulated a "history from above," many of them considered the model of the

studies on non-European Jews as well. See, for example, Emily Gottreich, The Mellah of Marrakesh: Jewish and Muslim Space in Morocco's Red City (Bloomington, IN, 2007); Heather Sharkey, Muslims, Christians, and Jews in the Modern Middle East (Cambridge, UK, 2017); Daniel J. Schroeter, "The Changing Landscape in Muslim-Jewish Relations in the Modern Middle East and North Africa," in Modernity, Minority, and the Public Sphere: Jews and Christians in the Middle East, ed. S. R. Goldstein-Sabbah and H. L. Murre-van den Berg (Leiden, 2016) 39-67.

${ }^{51}$ David Frick, "Jews and Others in Seventeenth-Century Wilno: Life in the Neighborhood," Jewish Studies Quarterly 12 (2005): 21-27. That was also the case in Muslim countries, as the example of Syria of the eighteenth and nineteenth centuries shows. See Nawja al-Qattan, "Litigants and Neighbors: The Communal Topography of Ottoman Damascus," Comparative Studies in Society and History 44 (2002): 511-33.

${ }^{52}$ See Edward Fram, "Two Cases of Adultery and the Halakhic Decision-Making Process," AJS Review 26 (2002): 277-300.

${ }^{53}$ Maria Cieśla, "Jewish Shtetl or Christian Town? The Jews in Small Towns in the PolishLithuanian Commonwealth in the 17th and 18th Centuries," in Jewish and Non-Jewish Spaces in the Urban Context, ed. Alina Gromova, Felix Heinert, and Sebastian Voigt (Berlin, 2015), 63-81.

${ }^{54}$ David Frick, "Jews in Public Places: Further Chapters in the Jewish-Christian Encounter in Seventeenth-Century Vilna," Polin 22 (2010): 220ff. This was also the case in Western Europe. See Baumgarten, Mothers and Children, 8.

${ }^{55}$ Magda Teter, Jews and Heretics in Catholic Poland: A Beleaguered Church in PostReformation Era (Cambridge, UK, 2006), 66-67.

${ }^{56}$ David Biale, ed., Cultures of the Jews: A New History (New York, 2002). Traditional historians tended to disregard differentiations among Jews and instead adhered to the notion of a united Jewry. The work of Jacob Katz is exemplary of this approach. See Debra Kaplan, "Jews in Early Modern Europe: The Sixteenth and Seventeenth Centuries," in History Compass 10, no. 2 (2012): 193. On Jacob Katz as a historian, see Ivan G. Marcus, "Israeli Medieval Jewish Historiography: From Nationalist Positivism to New Cultural and Social Histories," Jewish Studies Quarterly 17 (2010): 261, and Jay M. Harris, ed., The Pride of Jacob: Essays on Jacob Katz and His Work (Cambridge, MA, 2002). 
Berlin Haskalah the standard pattern of Jewish modernization. ${ }^{57}$ It implied that Jews outside of Germany followed the path of Mendelssohn and other German maskilim for curbing the influence of traditional Judaism. This view changed, however, when scholars shifted their attention away from a few elite Jews and investigated ordinary Jews not known for intellectual achievements, such as those in Amsterdam and London. Historians could demonstrate that decades before Moses Mendelssohn became active in Berlin a considerable part of Jews in these two cities had pursued a way of life beyond the constraints of traditional Judaism. ${ }^{58}$ Those Jews smoked and drank alcohol in public, shaved their beards, wore wigs, and spent their leisure time playing cards and dancing with non-Jews. ${ }^{59}$ What emerges, then, is the observation that Jews responded in locally and regionally different ways to what they considered the restrictive regimen of their religious authorities. ${ }^{60}$ This insight stresses the interdependence of Jews with their respective non-Jewish social surroundings and buttresses the idea of multiple Jewries. ${ }^{61}$

As illustrated by the memoir of Hans Ulrich Krafft (1550-1621), the contextual embeddedness of Jews also finds expression in a sense of regional be-

\footnotetext{
${ }^{57}$ Although a growing number of scholars depicted paths to modernization without Haskalah as early as the beginning 1980s, many historians continued to see the German-Jewish enlightenment as its formative pattern. See Todd M. Endelman, "In Defense of Jewish Social History," Jewish Social Studies 7, no. 3 (2001): 56-57; Moshe Rosman, "Haskalah: A New Paradigm," Jewish Quarterly Review 97 (2007): 129-36. In the following decade, the term "port Jew," which Lois Dubin coined in the 1990s, became a fixture in scholarly discourse. It first appeared in print in David Sorkin's article "Enlightenment and Emancipation: German Jewry's Formative Age in Comparative Perspective," in Comparing Jewish Societies, ed. Todd M. Endelman (Ann Arbor, 1997): 104-05. According to Dubin and Sorkin, the term designates a category of "acculturated Jewish merchants in port cities whose path towards integration in early modern Europe was distinctive." See Lois Dubin, "Researching Port Jews and Port Jewries: Trieste and Beyond," Jewish Culture and History 4 (2001): 47. Research on port Jews provided a particularly forceful alternative to the Berlin Haskalah as a model of modernization. Regarding port Jews, see also David Cesarani, "Port Jews: Concepts, Cases and Questions," Jewish Culture and History 4, no. 2 (2001): 1-11; Jonathan D. Sarna, "Port Jews in the Atlantic: Further Thoughts," Jewish History 20 (2006): 213-19. On the issue of Jewish modernization it is also worth looking at Sephardic Jews in northwestern and central European cities. See Yosef Kaplan, An Alternative Path to Modernity: The Sephardi Diaspora in Western Europe (Leiden, 2000).

${ }^{58}$ See Todd M. Endelman, The Jews of Britain, 1656 to 2000 (Berkeley, 2002).

${ }^{59}$ Shmuel Feiner, The Origins of Jewish Secularization in Eighteenth-Century Europe, trans. Chaya Naor (Philadelphia, 2010).

${ }^{60}$ In this context, we may also refer to the Frankist movement in Eastern Europe. See Paweł Maciejko, The Mixed Multitude: Jacob Frank and the Frankist Movement, 1755-1816 (Philadelphia, 2011).

${ }^{61}$ See the special issue devoted to "Tradition and Transformation in Eighteenth-Century Europe: Jewish Integration in Comparative Perspective" in Jewish History 24 (2010).
} 
longing that transcends identification with Jews from other regions. ${ }^{62} \mathrm{Krafft}$ was a Protestant merchant from southern Germany. He plied his trade in the Levant, primarily in Tripoli (Lebanon), where after a series of mishaps he was sentenced to jail. Among the Jews he became acquainted with in prison was a fellow German named Mayer Winterbach, who had grown up in Krafft's home region of Swabia. Owing to their mutual geographical origin, Krafft and Winterbach shared cultural traditions that laid the groundwork for a close friendship. Winterbach's regional identification was decisive not only for his feelings of closeness to Krafft, but also for his sense of estrangement from Levantine Jews. ${ }^{63}$ Krafft and Winterbach were only one of various other examples of interconfessional friendship based on shared cultural traditions. ${ }^{64}$

The acknowledgment of a heterogeneous, spatially fragmented Jewry ${ }^{65}$ raises the question of whether it is still possible to conceive of Jews as a unified group distinguishable from the non-Jewish world. What are the defining properties of a self-understanding that is constituted in part by mutual exchange with non-Jewish surroundings? Or, as David Biale has put it: What links the idea of one Jewish people to the history of manifold Jewish cultures? ${ }^{66}$ A number of scholars have given perceptive answers. They can be gathered from a broad range of studies, including research on the early modern period in Europe, ${ }^{67}$ the interior design of Jewish households, ${ }^{68}$ and con-

${ }^{62}$ On regional belonging, see also Yosef Hayim Yerushalmi, "Exile and Expulsion in Jewish History," in Crisis and Creativity in the Sephardic World, 1391-1648, ed. Benjamin R. Gampel (New York, 1997), 3-22.

${ }^{63}$ Daniel Jütte, "Interfaith Encounters between Jews and Christians in the Early Modern Period and Beyond: Toward a Framework," American Historical Review 118 (2013): 393.

${ }^{64}$ See Michael Heberer, Aegyptiaca Servitus: Das ist / Wahrhafte Beschreibung einer Dreyjährigen Dienstbarkeit / So zu Alexandrien in Egypten jhren Angang und zu Constantinopel jhr Endschafft genommen (Heidelberg, 1610; repr., Graz, 1967).

${ }^{65}$ In writing spatially instead of geographically, I deliberately refer to the concept of space and Jews' embeddedness in a material as well as socially constituted environment. On Jews and space, see Charlotte Elisheva Fonrobert, "The New Spatial Turn in Jewish Studies," AJS Review 33 (2009): 155-64; Vered Shemtov, "Between Perspectives of Space: A Reading of Yehuda Amichai's 'Jewish Travel' and 'Israeli Travel',' Jewish Social Studies 11, no. 3 (2005): 141-61; Simone Lässig and Miriam Rürup, Space and Spatiality in Modern German-Jewish History (New York, 2017).

${ }^{66}$ A recently published anthology discusses this aspect in the introduction; see Jakob Egholm Feldt and Maja Gildin, "Experience, Space, and Time in Jewish Cultural History: A Pragmatist Approach," in idem, New Perspectives on Jewish Cultural History: Boundaries, Experiences, and Sensemaking (New York, 2020), 1-26.

${ }^{67}$ David Ruderman proposes five markers that allow him to write about a shared historical experience of early modern Jewry, that is, "the singularity of early modern Jewry as a whole." See David B. Ruderman, Early Modern Jewry: A New Cultural History (Princeton, NJ, 2011), 58.

${ }^{68}$ Leora Auslander, '’Jewish Taste?' Jews and the Aesthetics of Everyday Life in Paris and Berlin, 1920-1942," in Histories of Leisure, ed. Rudy Koshar (Oxford, UK, 2002), 299-318; 
sumption culture. ${ }^{69}$ Kerry Wallach's work is of particular importance in this regard. She investigates the visibility of Jews in Weimar Germany, the codes of their Jewishness articulated by way of attire or behavior and revealed in particular situations or kept concealed in others. ${ }^{70}$ According to Wallach, Jewishness is difficult to decipher, though more easily for Jews than for nonJews. ${ }^{71}$ These studies demonstrate that multiple Jewish cultures are often connected by subtly expressed and frequently nonreligious symbols, and thus seem to buttress the idea of a single Jewish people.

\section{The Limits of Exchange and Interaction Historiography}

Hans Ulrich Krafft's memoir suggests that a sense of regional belonging may eclipse an awareness of difference and facilitate meaningful contacts between people of different ethnic and religious backgrounds. ${ }^{72}$ People involved in such encounters often develop or discover commonalities that form an indispensable basis for the development of closer and more intimate relations. According to Helmut Walser Smith, such commonalities, friendships, and mutual trust existed between Jewish cattle traders and non-Jewish peasants in southern Germany in the early twentieth century. Interethnic friendships flourished despite widespread accusations of Jewish usury. ${ }^{73}$ The shared ground between Jewish traders and non-Jewish peasants "concerned life, work, and value in the German countryside.... The argument is not that difference did not exist; that animosity did not exist; ... Rather, the argument is that everyday relationships were also marked by other dimensions: community ties (as well as antagonisms), a language more common than anti-Semitic agitators allowed, and ... trust." 74

eadem, "The Boundaries of Jewishness, or When Is a Cultural Practice Jewish?" Journal of Modern Jewish Studies 8 (2009): 47-64.

${ }^{69}$ Paul Lerner, The Consuming Temple: Jews, Department Stores, and The Consumer Revolution in Germany (Ithaca, NY, 2015).

${ }^{70}$ Kerry Wallach, Passing Illusions: Jewish Visibility in Weimar Germany (Ann Arbor, MI, 2017).

${ }^{71}$ Auslander, "Boundaries of Jewishness," 48-49. See Henry Bial's references to double coding in his book Acting Jewish: Negotiating Ethnicity on the American Stage and Screen (Ann Arbor, MI, 2005).

${ }^{72}$ Regarding meaningful contacts see Gill Valentine, "Living with Difference: Reflections on Geographies of Encounter," Progress in Human Geography 32 (2008): 325.

${ }^{73}$ Helmut Walser Smith, "The Discourse of Usury: Relations between Christians and Jews in the German Countryside, 1880-1914," Central European History 32 (1999): 266-67.

${ }^{74}$ Smith, "Discourse of Usury," 266. 
Smith's broad analytical approach successfully fleshes out the major theoretical propositions discussed in the present article. He draws particular attention to the gulf between quotidian experiences of Jews and non-Jews on the one hand and anti-Semitic propaganda on the other. While ideologues emphasized indelible differences between Jews and non-Jews, the challenges of the everyday often induced defiance of the dire warnings against doing business or socializing with Jewish traders. ${ }^{75}$ At times, the peasants brazenly sided with Jews who were the object of unjustified accusations.

Not unlike the research of exchange historians, Smith's essay-an excellent example of interaction historiography - shatters some premises of traditional historiography. Yet, his investigation also evinces the limits of interaction historiography's innovativeness-limits that scholars of Jewish and non-Jewish cultural transfer face as well. Whereas both groups of historians have revised older historical narratives and broadened the scope of knowledge of Jewish experience, their methodological approaches have perpetuated a defining characteristic of traditional historiography: all three historiographical camps tend to consider relations between Jews and non-Jews as dichotomous. This conception worked well for traditional historians, whose claim of a largely insular Jewish existence rested on a binary understanding of Jewish and non-Jewish connections. Exchange and interaction historians, however, view Jews and non-Jews as co-constituted and mutually involved with one another, which leads them to question, and even outright dismiss Jewish/non-Jewish dualism. Such an analytical approach based on a dichotomous classification is at odds with the outcome of their research, which erodes the binary.

Exchange and interaction pursue different ways to tackle this problem. Exchange historians tend to adopt a somewhat defensive position, that is, they maintain the contrast between Jews and non-Jews by downplaying the effects of their research on cultural transfer. To corroborate my thesis, I draw attention to pertinent assertions in Debra Kaplan's seminal research on Jewish and non-Jewish cultural reciprocity in the early modern period. Kaplan maintains that it is "abundantly clear that Jews were part of the societies in which they lived." Yet, she also cautions against overly far-reaching conclusions from extant work on cultural interdependency, claiming that "while borders ... were remarkably permeable" and thus allowed for cultural exchange, "many boundaries remained between Jews and their neighbors. This

\footnotetext{
${ }^{75}$ This is not to say that scholars studying the everyday always dig up commonalities between different groups. There are various examples that emphasize differences as well. See Avraham Grossman, Pious and Rebellious: Jewish Women in Europe in the Middle Ages (Hanover, NH, 2004), and Maria Cieśla, "Communities and Their Temples: Orthodox, Jewish, Protestant, and Catholic; Religious Delimitations in the Historical Topography of Słuck," Acta Historiae Polonica 116 (2017): 7-33.
} 
dimension of the Jewish experience at times gets lost in scholarship, which instead highlights the interactive, entangled aspects of Jewish history." 76 The multifarious cultural ties and interactions notwithstanding ("just as Jews and non-Jews lived together"), they also "really lived apart" in that Jews "were seen as others [by non-Jews] and vice versa." 77

While exchange historians observe the dissolution of Jewish particularity and respond by stressing the existence of boundaries, ${ }^{78}$ interaction historians encounter a different problem. In the face of multitudinous commonalities between Jews and non-Jews, they lament the lack of analytical tools that would allow scholars both to determine differences and acknowledge similarities between the two groups. In his exploration of memoirs, for example, Smith finds few distinctions between Jewish merchants' and non-Jewish peasants' attitudes regarding economic values and business practices. Consequently, tensions between the two groups unfolded "within a shared consensus about what counted as fair and just economic behavior" rather than being provoked by fundamentally different conceptions of life and work. ${ }^{79}$ Smith concludes: "What historians may need, then, is a theory of difference that can account for what Jews (and perhaps some Christians) felt to be underlying similarities." 80 Exchange and interaction historians thus strive for an understanding of commonalities and differences between Jews and nonJews that neither obfuscates boundaries nor obscures shared ground between them. However, lacking adequate approaches, they cannot help but fall back upon traditional historians' dichotomous categorization.

\section{Writing History beyond a Jewish/Non-Jewish Dualism}

Smith is not the only scholar who problematized the use of similarity and difference as polar opposites. In recent years, other researchers have expressed their dissatisfaction with using terms that insufficiently describe the interconnectedness of Jews and non-Jews. Some, like Elisheva Baumgarten, have addressed the issue in innovative ways. In her research on wet-nursing practices in the thirteenth century, Baumgarten notes that Christian sources "accuse Jews of forcing their Christian wet-nurses to refrain from nursing Jewish children for three days after they received communion." She continues: "If

\footnotetext{
${ }^{76}$ Kaplan, "Jews in Early Modern Europe," 196.

${ }^{77}$ Ibid.

${ }^{78}$ See Bryan Cheyette, Diasporas of the Mind: Jewish and Postcolonial Writing and the Nightmare of History (New Haven, 2013), 6.

${ }^{79}$ Smith, "Discourse of Usury," 270.

${ }^{80}$ Ibid., 270.
} 
the Jews indeed did that which they were accused of ... the Jews must have attributed some power to the Eucharist." ${ }^{\text {"1 }}$ In other words, specific facets of Christian belief seem to have seeped into the everyday culture of Jews. This example reveals the existence of shared ground but is also indicative of boundaries between Jews and non-Jews. There is no "either difference or similarity"- both play out concurrently. Baumgarten sustains this concomitance by stating that "one of the interesting ideas that recent research has pointed to in a variety of areas, is that this difference does not express itself as one perhaps expects or assumes. Minority groups took on majority practices and adapted many details from the surroundings." ${ }^{.2}$ In place of duality, Baumgarten conceives of similarity and difference as "two continuums." ${ }^{83}$ We also see the "both-and constellation" in her suggestion that we use the term entanglement for describing Jewish/non-Jewish relations. Entanglement, Baumgarten contends, "may include hostile as well as tolerant encounters." 84

Working on a different time period as well as a different social and cultural environment, Hasia R. Diner has also sought to dismantle the Jewish/nonJewish binary. While her analytical approach is less developed than Baumgarten's, Diner focuses more rigidly on commonalities and numerous affective ties between Jews and non-Jews. In her study of Jewish peddlers in the New World, Diner argues that their contacts with non-Jewish clients "erased linguistic, national, and religious differences as barriers to human interaction. Over time, the peddlers ceased to be alien, as customers noticed what they and the peddlers had in common." ${ }^{85}$ Unlike Baumgarten, Diner does not concentrate on Jewish and non-Jewish interconnectedness, let alone differences, but focuses instead on shared ground. In narrating the experiences of individual peddlers who spent their nights in the homes of non-Jewish clients, befriended them, and were invited to become part of non-Jewish communities, Diner primarily explores the development of mutual trust and intimacy.

\footnotetext{
${ }^{81}$ Baumgarten, “'A Separate People',” 219.

${ }^{82}$ Ibid.

${ }^{83}$ Ibid., 214.

${ }^{84}$ Elisheva Baumgarten, Ruth Mazo Karras, and Katelyn Mesler, "Introduction," in idem, Entangled Histories: Knowledge, Authority, and Jewish Culture in the Thirteenth Century (Philadelphia, 2017), 2. Even though Baumgarten's research greatly contributes to a reconceptualization of Jewish and non-Jewish relations toward a nonbinary understanding, to some extent a dualistic thinking still characterizes her methodological approach, as her use of the term "Jewish minority" - as opposed to Christian majority—reveals. On the term "minority," see Gershon David Hundert, "An Advantage to Peculiarity? The Case of the Polish Commonwealth," AJS Review 6 (1981): 24.

${ }^{85}$ Hasia R. Diner, Roads Taken: The Great Jewish Migrations to the New World and the Peddlers Who Forged the Way (New Haven, 2015), 86.
} 
She records one incident in which Jewish immigrant Louis Jacob, a peddler in the vicinity of San Bernardino, California in the 1850s, was involved in a payment dispute with one David Seely, a Mormon elder. When Seely physically attacked Jacob, the Mormons sided with the peddler, not only forcing the elder to apologize, but stripping him of his ecclesiastical honors. ${ }^{86}$ This incident is one small example from the plentiful evidence of common ground between Jews and non-Jews, in the particular case of values that transcend their boundaries.

\section{The Turn to Commonalities}

Baumgarten and Diner provide new perspective on Jewish/non-Jewish relations. Neither denies differences between the two groups, but differences are not fundamental to their analysis. The new interpretations of ties between Jews and non-Jews are comparable to endeavors by scholars in non-Jewish history, urban studies, and other disciplines that reconceptualize relations between (national/ethnic/cultural/religious) groups. In what follows, I outline two developments in these fields and explain how recent attempts to rethink Jewish/non-Jewish ties cohere with this wider context.

The first development, prominent above all in Habsburg studies, concerns the concept of (national) indifference. As Pieter Judson and Tara Zarah have demonstrated in numerous studies on the daily lives of ordinary people, most were unconcerned about national, ethnic, and cultural distinctions propagated by politicians, intellectuals, and ideologues. Although conventional historical accounts claim that nationalism tore apart the Austrian-Hungarian monarchy decades before its final demise, ${ }^{87}$ common folk were surprisingly resistant to thinking along ethnic or nationalistic lines. As a German-speaking peasant in Bohemia summed up the attitude among rural people toward nationalism in 1879: "We know nothing of national hatred ... of what importance is nationality to the peasant?" 88 This is not to say that the ethnically heterogeneous Habsburg monarchy lacked national or nationalistic sentiments. However, as Judson maintains, such emotions were often solely situational, bound to specific events. ${ }^{89}$ When the topicality of these incidents faded, national or na-

\footnotetext{
${ }^{86}$ Ibid., 109.

${ }^{87}$ Alan Sked, The Decline and Fall of the Habsburg Monarchy 1815-1918 (London, 1989).

${ }^{88}$ Pieter M. Judson, "Inventing Germans: Class, Nationality and Colonial Fantasy at the Margins of the Habsburg Monarchy," Social Analysis 33 (1993): 53.

${ }^{89}$ Taking account of the specific circumstances surrounding different forms of selfunderstanding is not new to historical research. The work of German-Canadian historian Till van Rahden is illuminating with regard to Jews and Jewish history. In the 1990s, he wrote
} 
tionalistic feelings also dissolved. Instead of national fervor, an attitude of national indifference predominated. ${ }^{90}$

Indifference is a promising analytical instrument for investigating everyday relations between national, religious, ethnic, and other groups, particularly between Jews and non-Jews. It shifts the focus of investigation from interethnic isolation, at times enmity and even violence, to widely peaceful coexistence and light-hearted interactions. At its root, indifference does not dissolve dichotomous (ethnic, religious, national) categorizations, but mitigates their significance. Historians of the Jewish past have been aware of indifference in Jewish/non-Jewish relations long before it became a prominent analytical tool in historiography. It forms the conceptual basis, for example, of a large part of Gershon David Hundert's work on the history of Jews in Poland. In 1984, Hundert co-authored a book with Gershon C. Bacon in which they convincingly argue that Polish historiography never mentioned Jews as a corporate entity. The frequent references to Jews almost always address individuals who figure as "an undifferentiated part of the social fabric." 91

Hundert's text was published three and a half decades ago. Numerous subsequent studies have revealed that a sense of indifference often characterized

about the situational ethnicity of the Jews in Breslau. In using this term, he argued that Jewish self-understanding is not an unwavering constant, but rather bound to concrete circumstances. See Till van Rahden, "Weder Milieu noch Konfession: Die situative Ethnizität der deutschen Juden im Kaiserreich in vergleichender Perspektive," in Religion im Kaiserreich: Milieu, Mentalitäten, Krisen, ed. Olaf Blaschke and Frank-Michael Kuhlemann (Gütersloh, 1996), 409-34. See also by van Rahden, Juden und andere Breslauer: Die Beziehungen zwischen Juden, Protestanten und Katholiken in einer deutschen Großstadt von 1860 bis 1925 (Göttingen, 2000), in which he formulated a heuristic framework for examining Jewish selfconsciousness as fragmented, fluid, and plural.

${ }^{90}$ Pieter M. Judson and Tara Zahra, "Introduction," Austrian History Yearbook 43 (2012): 21-27. Similar concepts are known by the terms histoire croisée and entangled history. See, for example, Michael Werner and Bénédicte Zimmermann, "Vergleich, Transfer, Verflechtung: Der Ansatz der Histoire croisée und die Herausforderung des Transnationalen," Geschichte und Gesellschaft 28 (2002): 607-36; Micha J. Perry and Rebekka Voß, "Approaching Shared Heroes: Cultural Transfer and Transnational Jewish History," in Jewish History 30 (2016): 1-13. In this context, it is also worth mentioning Moritz Csáky's concept of plurality. With regard to his work on Vienna around 1900, he notes that due to the multilingualism as well as the plural cultural identifications of the city's inhabitants, it is sometimes difficult, if not impossible, to assign them to a specific group; see Moritz Csáky, Das Gedächtnis der Städte: Kulturelle Verflechtungen - Wien und die urbanen Milieus in Zentraleuropa (Vienna, 2010), 357-58. These works paradigmatically demonstrate that a sense of social belonging is often stronger than and transcends national or ethnic dividing lines. See also Pieter M. Judson, The Habsburg Empire: A New History (Cambridge, MA, 2016), 4-5.

${ }^{91}$ Gershon David Hundert and Gershon C. Bacon, The Jews in Poland and Russia: Bibliographical Essays (Bloomington, IN, 1984), 2-3. Quoted in Gershon David Hundert, "Polish Jewish History," Modern Judaism 10 (1990): 260. 
Jewish and non-Jewish coexistence. ${ }^{92}$ In this respect, Yohanan PetrovskyShtern's research on the Polish shtetl of Balta provides an illustrative case study. Based on the results of his fascinating work, Petrovsky-Shtern writes that Balta's marketplace "proved that a shared pool of values, interests and ideas united the local urban Christian administration and the Jewish community. The language of the local administrative documents reveals no attempts to distinguish between the Christian and the Jewish urban residents. Both groups - as well as non-specified Tartars and Poles-were seen as legitimate and jointly contributing to the town's development." 93 An attitude of indifference found expression not only in the language of Balta officials, but in the unfolding of the everyday as well. When a fire broke out in a district heavily populated by Jews, the local police, firemen, and merchants made a joint effort to save the area. After assessing the damage, the local authorities administered social relief to those in need. They made no distinction between Jews and non-Jews. ${ }^{94}$

Over the last few years, scholars at the University of Tübingen collaborated with colleagues at the University in Konstanz and Anil Bhatti from New Delhi in elaborating another analytical concept, similarity. Its protagonists claim that its main goal is to overcome binaries by highlighting intergroup commonalities. ${ }^{95}$ As is the case with indifference, scholars working with similarity do not disclaim the existence of distinctions between groups or their individual members. But in considering their manifold commonalities, these distinctions are no longer considered essential. Instead, similarity and difference are viewed as relating to and differing only gradually from each other. ${ }^{96}$ The abandonment of the binary is not the only aspect in which the concept of similarity differs from the model of indifference. Another distinction concerns relationships that people have with one another. Indifference merely indicates that individuals' identifications with different religious, ethnic, and other groups do not adversely affect their mutual interactions. But it tells us

\footnotetext{
${ }^{92}$ Magda Teter, for example, presents numerous cases of Jewish and non-Jewish interactions. In summarizing her work, Teter states that "Jews and Christians collaborated together and entered or shared each other's spaces, food, clothing, and even language. All this, however, is not to say that there were no differences between Jews and Christians. Such differences certainly existed but were, perhaps, not as stark as modern historians want us to believe." See Kaplan and Teter, "Out of the Historiographic Ghetto," 391.

${ }^{93}$ Yohanan Petrovsky-Shtern, "The Marketplace in Balta: Aspects of Economic and Cultural Life," East European Jewish Affairs 37 (2007): 292.

${ }^{94}$ Ibid., 285-86.

${ }^{95}$ Anil Bhatti and Dorothee Kimmich, eds., Similarity: A Paradigm for Culture Theory (New Delhi, 2018).

${ }^{96}$ Albrecht Koschorke, "Similarity: Valences of a Post-Colonial Concept," in Bhatti and Kimmich, Similarity: A Paradigm for Culture Theory, 26.
} 
nothing about people's actual attitudes, whether they feel aversion or respect for each other. ${ }^{97}$ Similarity, on the other hand, has an affective dimension; people who perceive similarity with others feel empathy for them. ${ }^{98}$ Whenever they perceive similarity, they are aware of sharing specific cultural characteristics, experiences, a particular mindset or views, and thus empathize and display solidarity with each other.

An exemplary case of similarity came to the fore around the middle of the nineteenth century in the Polish town of Kiesielnice. In response to a complaint by a local Jew, Szlomo Wolfowicz Blumrozen, district officials investigated whether a fellow Jew, Zelka Wigdorowicz, was illegally operating a tavern. After interrogating numerous people on site, the authorities decided to expel Wigdorowicz from the town. Unexpectedly, however, they met with strong resistance from a group of local non-Jews who staunchly advocated for Wigdorowicz's right to stay. ${ }^{99}$ These townspeople did not behave indifferently towards the incriminated Jew, let alone espouse the commissioners' verdict, but took a stand for him. They expressed a relationship with Wigdorowicz that went beyond a simple disregard of ethnic or religious differences.

\section{Conclusion}

How do scholars benefit from employing the model of similarity? Is working with similarity just a passing whim of some academics, or does its application, as I firmly believe, effectively raise new questions, broaden neglected fields of research, and contribute to a new understanding of the Jewish past? After all, endeavors to move beyond the Jewish/non-Jewish binary are all but a new phenomenon. So what exactly is the additional value of using similarity? By avoiding the application of difference as an analytical tool, it surpasses other scholarly attempts to erode the Jewish and non-Jewish dualism, as I demonstrate in this final section of my essay.

\footnotetext{
${ }^{97}$ In this respect, indifference resembles what sociologists call bonding. See Klaus Hödl, "From Jewish Separateness to Jewish and Non-Jewish Entanglement: A Shift to a "New Jewish History'?" in New Perspectives on Jewish Cultural History, ed. Maja Gildin Zuckerman and Jakob Egholm Feldt (New York, 2019), 164-87.

${ }^{98}$ Aleida Assmann, "Similarity as Performance: A New Approach to Identity Construction and Empathy Regimes," in Bhatti and Kimmich, Similarity: A Paradigm for Culture Theory, 167.

${ }^{99}$ Glenn Dynner, "Legal Fictions: The Survival of Rural Jewish Tavernkeeping in the Kingdom of Poland," Jewish Social Studies 16, no. 2 (2010): 52.
} 
Historians have described the relationship between non-Jewish landowners and their Jewish leaseholders in Poland of the modern era as an "alliance of interests" in which Jews often enjoyed privileges and were protected by the noble aristocrats for whom they worked, while the magnates reaped large profits from the Jews' expertise in managing their latifundia. ${ }^{100}$ Both sides capitalized on this symbiotic relationship. According to Moshe Rosman, however, they remained committed to their relationship for more than pragmatic reasons. In these "marriages of convenience," as he calls the Jewish/non-Jewish alliances, "each side felt a mutual responsibility that transcended mere utility." ing of Jewish and non-Jewish ties by maintaining that they implicated an affective side as well. He recognizes a sense of mutual connectedness that scholars of similarity would deduce from an awareness of shared ground among Jews and non-Jews.

As this example underscores, similarity does not usher in a fundamentally new reading of the Jewish past. Instead, its proponents seize on interpretative perspectives that other researchers have already adopted. In drawing upon an elaborate conceptual framework, however, scholars of similarity advance these perspectives much further. And they exhaustively dig for instances of commonalities; their whole approach to Jewish/non-Jewish relations is determined by eschewing difference as an analytical tool. Consequently, they find feelings of similarity not only in the alliances between non-Jewish nobles and Jewish leaseholders, but among common people as well. ${ }^{102}$

In addition to provoking a partial reevaluation of the Jewish past, investigating experiences of similarity may also help answer a pressing question in Jewish studies - one that figures prominently in the study of antisemitism: Why do people who often maintained close relations with Jews suddenly, and seemingly remorselessly, turn violent against their former neighbors and acquaintances? ${ }^{103}$ I propose that as a factor we consider insufficient perceptions of interethnic and religious commonalities between non-Jewish perpetrators and their Jewish victims. In the particular case of Jews and non-Jews, unless contacts result in both bridging and actual bonding experiences, people may

\footnotetext{
${ }^{100}$ Israel Bartal, The Jews of Eastern Europe, 1772-1881 (Philadelphia, PA, 2002), 17.

${ }^{101}$ Moshe Rosman, The Lords' Jews: Magnate-Jewish Relations in the Polish Lithuanian Commonwealth during the Eighteenth Century (Cambridge, MA, 1990), 210.

${ }^{102}$ Salomon I. Horowitz describes such perceptions of similarity between Jews and non-Jews; see Lebenserinnerungen eines polnischen Juden, vol. 1, Kann ein Pole Antisemit sein? (Lemberg, 1909), 35.

103 Jan T. Gross, Neighbours: The Destruction of the Jewish Community in Jedwabne, Poland (Princeton, NJ, 2001); Jeffrey S. Kopstein and Jason Wittenberg, Intimate Violence: AntiJewish Pogroms on the Eve of the Holocaust (Ithaca, NY, 2018).
} 
well retain their biases and prejudices. With few exceptions, however, bonding occurs only in venues where people meet on a regular basis and pursue common goals, such as at work, school, or leisure clubs. ${ }^{104}$ Haphazard encounters on the street or at a theater performance, or socializing as neighbors, hardly engender strong feelings of attachment. ${ }^{105}$

I cite the biography of Helen Blank, a Jewish woman born in Vienna in 1917, in support of my proposition. In her memoirs, Helen notes that she managed to escape the Nazi regime by migrating to the United States in early 1939. A group of very close friends, Jewish and non-Jewish, accompanied her to the Vienna railway station to see her off. ${ }^{106}$ That is to say that at a time when it was at best unfavorable, perhaps even dangerous for nonJews to display their familiarity with Jews in public, Helen Blank's friends did not forgo the opportunity to bid farewell in person. Their mutual affective bonds proved stronger than the fear of potential consequences. ${ }^{107}$ Considering Helen Blank's biography, this behavior was not in the least surprising. Her life in the Habsburg metropolis offered numerous opportunities to meet and become emotionally attached to non-Jews, and she never socialized in an exclusive or predominantly Jewish milieu. Instead, she joined various clubs and leisure societies and attended schools where she discovered many similarities with non-Jews and vice versa. Those in her circle developed mutual trust, respect, and intimacy. Blank, in other words, frequented spaces where interethnic contacts easily developed into friendship.

The experiences of similarity between Helen Blank and her non-Jewish friends do not relativize the dreadful conditions under which Jews had to live shortly before the onset of the Shoah, neither do they obfuscate the daily anti-Semitism Jews had to face in Vienna at that time. Instead, they indicate a complexity, a dynamic intermingling of Jewish and non-Jewish relations that historians have yet to explore in depth. By employing the concept of similarity, we may be able to elucidate many more instances of intimate relations between Jews and non-Jews that, in sum, would also revise historical accounts of Jewish life in the past.

\footnotetext{
${ }^{104}$ Amin Ash, "Ethnicity and the Multicultural City: Living with Diversity," Environment and Planning A 34 (2002): 969.

${ }^{105}$ Valentine, "Living with Difference," 329.

${ }^{106}$ Helen Blank, "Growing up in Vienna, 1917-1939," Leo Baeck Institute Archives, LBI Memoir Collection (ME 1299), https://digipres.cjh.org/delivery/DeliveryManagerServlet?dps _pid=IE8799693.

${ }^{107}$ Insofar as similarity does not displace difference but merely renders it secondary, in the particular case of the rail station a sense of difference between Helen Blank and her nonJewish friends must have prevailed as well, since the latter did not have to flee the country in order to save their lives.
} 
Acknowledgments The research for this article was funded by the Austrian Science Fund (FWF), grant P31036-G28.

Funding Note Open access funding provided by University of Graz.

Publisher's Note Springer Nature remains neutral with regard to jurisdictional claims in published maps and institutional affiliations.

Open Access This article is licensed under a Creative Commons Attribution 4.0 International License, which permits use, sharing, adaptation, distribution and reproduction in any medium or format, as long as you give appropriate credit to the original author(s) and the source, provide a link to the Creative Commons licence, and indicate if changes were made. The images or other third party material in this article are included in the article's Creative Commons licence, unless indicated otherwise in a credit line to the material. If material is not included in the article's Creative Commons licence and your intended use is not permitted by statutory regulation or exceeds the permitted use, you will need to obtain permission directly from the copyright holder. To view a copy of this licence, visit http://creativecommons.org/ licenses/by/4.0/. 